\title{
The Birth of a Republic, but not of a Nation: \\ The case of state-building in Cyprus
}

\author{
NIKOLAS KYRIAKOU \\ University of Cyprus \\ NIKOS SKOUTARIS \\ University of East Anglia \\ 'Because in Cyprus the only thing that is Cypriot is the donkey' \\ Rauf Denktas, former leader of the Turkish Cypriot community
}

\begin{abstract}
The principle of bi-communality has been advanced as a founding feature of state-building in Cyprus. The aim of this paper is to provide for a systematic account of the different variations of the bi-communal principle enshrined in the Constitution of the Republic of Cyprus and in the Annan Plan as the most comprehensive proposal for the reunification of the island. In order to achieve its scope, the paper focuses on the provisions concerning State institutions and citizenship. It argues that in all those constitutional structures State-building is not linked with nation-building. In fact, the acceptance of bi-communalism as a fundamental principle of the united Cyprus proves that the main concern has been the accommodation of the political tensions resulting from a divided society.
\end{abstract}

Address correspondence to Nikolas Kyriacou, Department of Social \& Political Sciences, University of Cyprus, 1678 Nicosia, Cyprus. E-mail: kyriakou.a.nikolas@ucy.ac.cy Address correspondence to Nikos Skoutaris, Law School, University of East Anglia, Norwich Research park, Norwich, NR4 7TJ, United Kingdom. E-mail: N.Skoutaris@uea.ac.uk 


\section{A. Introduction}

In contrast with numerous state-building projects of the two past centuries, which had been centered on the idea of "one nation, one state", in the case of Cyprus the recognition of the existence of two constituent ethno-religious segments on the island has been advanced as a founding principle of state-building. Such recognition was mainly expressed by the principle of bi-communality. Bi-communality was met with resistance by political elites of the two major communities, mainly due to their

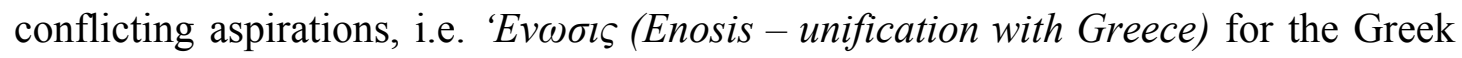
Cypriots and Taksim (partition) for the Turkish Cypriots. However, this principle not only prevailed as a fundamental characteristic of the London-Zurich agreements, but also survived in even more entrenched forms in all subsequent settlement plans and most saliently in the last UN-sponsored plan for a solution (the Annan Plan). ${ }^{1}$

The purpose of the present article is to provide for a systematic account of the different variations of the principle of bi-communality enshrined in the Constitution of the Republic of Cyprus (RoC) and the Annan Plan as the most holistic attempt to reunify the divided island. We focus on those two settlement plans not only because they are the most comprehensive so far but also because they both represent attempts to manage the Cyprus problem in accordance with the interests of external parties. In doing so, both fell foul of international norms that would contribute to their failure. In the case of the 1960 arrangement, it was clear that the Constitution and the Treaty of Guarantee by allowing for multiple ways for external parties to interfere in the affairs of Cyprus was contrary to the very notion of Cyprus as a sovereign independent state. In addition, as we shall see in the following part of the paper, the political institutions that were set up provided scant opportunities for the development of a Cypriot national identity to underpin such an entity. On the other hand, in the 
case of the Annan Plan, the conflict has been with the conventions that have been put in place in support of the rights of individuals from a liberal perspective. In fact, we argue that the Annan Plan somehow froze a particular inter-group configuration in time by following a rather corporate consociational logic. ${ }^{2}$

Our thesis is that in both those constitutional structures the Cypriot Statebuilding project is not linked with a nation-building one. In fact, the acceptance of bicommunality as a fundamental principle of the united Cyprus proves beyond doubt that the main concern of the constitutional architecture is the accommodation of the political tensions resulting from a divided society.

In order to achieve its scope, the article focuses on the relevant provisions concerning State institutions and citizenship. We consider that these two fields serve as stable indicators to our hypothesis that the overwhelming focus on securing the ethnic representation and crosschecks inevitably resulted in side-lining the discussion on a nation-building project for the island. Furthermore, the choice of these two areas is also dictated by the constitutional structure of the Republic and the envisaged united Cyprus. In the texts of both the Cypriot Constitution and the Annan Plan, a substantial number of provisions directly or indirectly refer to the political organization and institutional position of the two communities.

\section{B. The Constitution of RoC}

\section{Preliminary Remarks}

The content of the 1960 arrangement was formed by the surrounding historical and political factors at the time of its adoption. In this respect, the provisions therein were primarily intended to safeguard the interests of the three States involved in its drafting, i.e. the United Kingdom, Greece and Turkey. In particular, those three States 
guaranteed Cyprus' 'independence, territorial integrity and security" ${ }^{3}$ and the integrity of the UK Sovereign Base Areas. ${ }^{4}$ More importantly, the Guarantor States undertook to consult each other with respect to the 'measures necessary to ensure observance of those provisions'. However, 'in so far as common or concerted action may not prove possible, each of the three guaranteeing Powers reserves the right to take action with the sole aim of re-establishing the state of affairs created by the' Treaty. ${ }^{5}$ It was precisely this provision that was used as a legal basis for the 1974 Turkish military intervention and as such questioned from the very beginning the very notion of Cyprus as a sovereign independent state.

At the same time, the 1960 Constitution was failing to grasp the political aspirations of the citizens of the newly created State. In this regard, bi-communality was the meeting point of diverging political projects rather than a foundational myth to which Cypriots could aspire. Essentially, bi-communality ensured that the majority Greek Cypriot population would not exercise a determining degree of power over public affairs and, consequently, on the Turkish-Cypriot community. Further, Enosis and Taksim were expressly forbidden by the constitutional arrangement and the two communities were required to pursue a political project that had never been on their agendas before: independence and mutual cooperation. Time proved that this was not a viable option, mainly due to the antagonism between the elites of the two communities and the pervasive force of the dialectic of nationalism. ${ }^{6}$

\section{A bird's eye-view of the Constitution}

From the outset, Cyprus is proclaimed as "an independent and sovereign Republic with a presidential regime, the President being Greek and the Vice-President being Turk elected by the Greek and the Turkish Communities of Cyprus respectively". 
However, the founding stone of the Constitution is the existence of two communities and citizens belonging to either of them. In this respect, Article 2 of the Constitution defines the constituency of these communities in the terms of Greek or Turkish ethnic origin, language and cultural traditions and Greek-Orthodox or Moslem religion.

It is only through participation in either of the two communities that Cypriot citizens can exercise the full range of their rights and duties. The division along ethnic lines runs through the entire text of the Constitution, bringing within the realm of bicommunality the operation of all three branches of power; taking up office to public organs by way of fixed quotas reserved for each community; and an exhaustive list of competences that may be exercised or blocked by public officials, most importantly the veto rights of the President and Vice-President of the Republic. These rights could effectively paralyze the operation of the State.

The Council of Ministers comprises ten ministers, which are allocated on a 7:3 ratio between the two communities. In fact, this ration applies also to the number of the members of the Parliament, the members of the public service and the Public Service Commission and the security forces of the Republic. This balance is altered in the case of the army (6:4 ratio) and that of the independent bodies and officials. Last, the members of the judiciary were fixed to one representative from each community, plus a foreign judge in the case of the Supreme Constitutional Court and two Greeks, one Turk and one foreign judge in the case of the Supreme Court.

Another salient feature of the Constitution is the exhaustive list of competences that both the President and the Vice-President are endowed with. The Constitution comprises a detailed enumeration of their respective powers, as well as the instances in which they may exercise veto powers. In essence, the ultimate 
decision or blocking power rested with the two representatives of the Executive. This situation should be understood as the ultimate hurdle to the decision-making process.

Another characteristic of the Constitution was the designation of some of its provisions as "basic" articles, which "cannot, in any way, be amended, whether by way of variation, addition or repeal" ${ }^{8}$ Hence, the drafters of the Constitution created a cumbersome constitutional setting under the belief that, by securing the unchangeable nature of a significant part of the Constitution, the politically inexperienced communities would find their ways through this legal maze.

\section{State Institutions}

In all three branches of power, the two communities worked exclusively along the basis of their ethnic affiliation. The Executive was under the heavy influence of President Makarios and Vice-President Küçük, the two figures that had led the struggle of their respective ethnic groups for self-determination.

The House of Representatives and the Communal Chambers proved to be the playground for nationalistic fronts on both sides to advance their rhetoric through the media coverage that the two bodies offered. ${ }^{9}$ As far as the two Communal Chambers are concerned they were the showcases for the ethnic isolation of both communities. Among their respective competences were all educational, cultural and teaching matters. Inevitably, this entailed the continuation of nationalistic discourse by other means, especially through public education. In the years that followed, the Church and students of public schools proved to be the prime exponents of Greek irredentism. Conversely, the rise of Turkish Cypriot nationalism as a counteraction to Greek irredentism exacerbated the tensed political climate. ${ }^{10}$ In the case of the Communal Chambers, the lamentably lost opportunity was the failure to create a common public 
space where the new generation of Greek and Turkish Cypriots would be educated together.

The Greek Cypriot political elite offered numerous occasions to its Turkish Cypriot counterpart to doubt its commitment to the new state of affairs. Public statements by President Makarios and Greek Cypriot ministers ${ }^{11}$ referred to the "struggle that continues" 12 and contained a persistent revisionist view of the Constitution. Conversely, the Turkish Cypriot elite considered the "London-Zurich Republic" as a "transitory phase" towards the "final solution". ${ }^{13}$

The hallmarks of the inability to reach compromises were the failure to agree on the issues of separate municipalities and taxation within the parliament. After the events of 1963-64 and the passing over of the exclusive control of the Republic to the Greek Cypriots, the House of Representatives passed a unanimous resolution declaring that the struggle would continue until the achievement of Enosis. ${ }^{14}$ The Greek Cypriots had not abandoned Enosis as their political vision, which explains to a large extent their unwillingness to cooperate with Turkish Cypriots for the effective operation of the new State.

Bi-communality was also visible at the level of the electoral constituency. The two communities were required to elect the members of the parliament and the President and Vice-President through separate electoral processes. Inescapably, this had both practical and political ramifications: Greek and Turkish Cypriots were registered in separate electoral rolls and followed different campaigns. To our understanding, this issue lies at the intersection of the two distinct fields we examine in this article, namely State institutions and citizenship. We consider that the constitutional scheme for citizenship is a notion inescapably entwined with the 
shaping of the political units of the two communities, which, in turn have the right to elect State institutions.

The mutual suspicion and lack of trust is evidenced by numerous incidents that reinforced the mistrust of the respective leaderships and discouraged cooperation. The submission of 13 points for the revision of the Constitution by President Makarios was the showcase of the revisionist stance of the Greek Cypriot side. The proposal intended to neutralize the political position of the Turkish Cypriots by downsizing their ratio of representation to their actual population size, unifying the judiciary and abolishing the veto powers of the President and Vice-President, as well as the separate majorities that were needed in the House of Representatives.

Makarios' proposals would establish a majoritarian rule, which prima facie seemed concordant with democratic precepts. However, given the political circumstances on the island, they were politically non-pragmatic since they sought to fully reshape the power sharing scheme and public affairs that was reached through the 1960 agreements. ${ }^{15}$ Expectedly, the proposals were singlehandedly rejected by the Turkish Cypriots and formed part of an escalation of events that led to the first partition of the island. After the events of 1963 and 1974, and due to the deprivation of all electoral rights for Turkish Cypriots residing in the areas under the effective control of the Government of Cyprus, a Turkish Cypriot citizen challenged this before the European Court of Human Rights (ECtHR). The latter found that:

'the applicant, as a member of the Turkish-Cypriot community living in the government-controlled area of Cyprus, was completely deprived of any opportunity to express his opinion in the choice of the members of the House of Representatives of the country of which he is a national and where he has always lived'. ${ }^{16}$ 
The ECtHR thus brought an end to the decades-long lack of legislation, which operated as a tool of exclusion directed against Turkish Cypriots.

In 2006, the same Court declared inadmissible the application of two Turkish Cypriots, who, conversely to the previous case, resided in the Turkish-occupied areas. The applicants had requested "to be placed on a separate electoral list, namely, a Turkish electoral list, in order to vote and stand for the parliamentary elections". Interestingly, the Court rejected their complaints and went on to state that:

'Even if it were [valid to compare themselves to the Turkish Cypriots residing in the Government Controlled Areas], for the reasons given above, there is objective and reasonable justification and a legitimate basis for distinguishing for electoral purposes between those Turkish Cypriots who chose to remain in the "TRNC" under the day-to-day administration of the de facto authorities and those Turkish Cypriots who lived within the area controlled by the Government, subject to the direct impact of the measures adopted by the legislature of the Republic.' 17

To our view, this excerpt confirms our understanding of the hiatus within the sociopolitical fabric of Cypriot society. The two communities continue to be perceived as two distinct political units destined to be antagonistic to each other. More fundamentally, it confirms a crude reality: since 1963 with the first partition, and 1974 with the forcible segregation of the population and the geographical division, the two communities cannot engage in meaningful and multi-layered political communication. The exceptions to this are the informal mini-sized rapprochement groups and part of the political leadership of the two communities. ${ }^{18}$

To sum up, the Greek Cypriot political elite had never accepted the 1960 arrangement and maintained a persistently revisionist view towards achieving Enosis. 
On the other side of the political spectrum, the Turkish Cypriots insisted on the letter of the Constitution, missing many times the expediencies of reality.

\section{Citizenship}

The 1960 arrangement encapsulated the transitional arrangements on the acquisition of citizenship. ${ }^{19}$ The Constitution provided that "any matter relating to citizenship shall be governed by the provisions of Annex D to the Treaty of Establishment." ${ }^{20}$ In turn, Annex D granted citizenship to persons that had been accorded the subject of British subjects by way of colonial legislation or were born in the island after 1914, provided that they had ordinarily resided in Cyprus at any time in the period of five years immediately before the date of the Treaty of Establishment. ${ }^{21}$

Article 2 of the Constitution provided the criteria of language, cultural traditions and religion as indicators of participation in either community. At the same time, this arrangement did not envision the option of non-participation in either community. Citizens were free to opt to belong to the community of their choice and exit from it, but should they decide to exit one, they would automatically be delegated to the other community. Another blind spot of this arrangement was the fact that minority groups that did not meet the criteria set out in the Constitution were obliged to collectively choose their membership to either community. Eventually, this resulted in three religious groups choosing to be considered part of the Greek Cypriot community.

For the most part of the population, meeting all three criteria was the rule. The Greek fraction of the population spoke Greek, was Greek Orthodox and shared Greek cultural traditions. The same can be said for the Turkish segment of the population that was predominantly Moslem, spoke Turkish and partook to the Turkish cultural 
traditions. Contrary to the classical liberal tradition, which endows individuals with the capacity of citizen based solely on the relationship between the State and the individual and is colourblind to any other attributes, the Cypriot paradigm is premised on an ethnically mediated citizenship. In other words, to be a citizen of the Republic an individual must first demonstrate possession of at least one characteristic that places him/her within one ethnic community. It is only through this communal participation that an individual can be regarded as a citizen.

In essence, individuals are required to take upon themselves a specifically delineated and pre-ordained identity, which places them in a separate and competing group of persons. As a consequence, the nationalistic discourse that had been prevalent in both communities before independence was officially endorsed and confirmed within the new legal order. The communal division was not only legally entrenched in the new Constitution, nor was it solely of a symbolic nature. The ascendance of Archbishop Makarios III and Dr. Fazil Küçük to the offices of President and Vice-President of the Republic respectively, sealed the nationalistic antagonism between the two communities and shaped the political discourse between the two for many years. ${ }^{22}$ Both were representative figures of their communities' conflicting aspirations and none of the two political figures had ever sincerely endorsed the new state of affairs. From the highest official posts to the plain citizens of the Republic, the message was that the communal identity and loyalty were the two single most important values to be guarded.

The antagonism between the political elites of the two communities was underpinned by a deep-rooted and relentless suspicion against each other. On the one side, the Greek Cypriots considered that the London-Zurich agreements were flawed for two main reasons: first, they were considered as an impediment to the realization 
of the claim for self-determination and Enosis and second, they were thought to unjustly afford the Turkish Cypriot community a quota representation in State institutions that exceeded its actual population size. On the other side, the Turkish Cypriots would not accept any arrangement that would relegate their community to merely a minority group, preordained to follow the political destiny of Greek Cypriots.

Another problematic feature of the mediated capacity for citizenship was the position of minority groups. Soon after independence, three religious groups were officially recognized. Armenians, Maronites and Latins (Roman Catholics) chose to join the Greek Cypriot community. Accordingly, together with their particular ethnic, religious and linguistic characteristics, they were essentially forced to fit into the straightjacket of a new identity, with which they had little, if no, affinity. This constitutional arrangement may have been dictated by the political realities of the 1960s, but nowadays can only be seen as problematic. In this connection the Advisory Committee of the Framework Convention for the protection of National Minorities has criticized this state of affairs in all three Opinions it has issued on RoC. In addition, it has been pointed out that:

"in the Cypriot system, political integration operates through the mediation of cultural communities; it is through the affiliation with a cultural community that individual citizens participate in the political institutions. This conflicts with a critical dimension of contemporary international minority rights, namely the idea that people should be free to identify or not with a cultural group". 23

The latter observation clearly illustrates the intrinsic relationship between citizenship, participation in public affairs and State institutions. In fact, this criticism is equally 
applicable to the full spectrum of different groups on the island and not only to the three religious groups. However, we do acknowledge that in the broader scheme of the Cyprus issue the treatment of minorities and their effective political representation was neither a key issue nor a decisive point for the success or failure of the Statebuilding project.

The division of citizens along the lines of ethnic affiliation was not devised by the 1960 arrangement. It is the historical legacy of the immediately preceding state of affairs that had paved the way for this arrangement. In the bodies that were set up by the British colonial administration the two communities were allowed to be represented not as a whole, but as group collectivities that were defending solely their communities' interests. ${ }^{24}$ Instances of cross-communal cooperation were scarce, thus shaping the competing position of the two communities. At the same time, the emergence of Greek and Turkish nationalisms on the island precluded any serious attempts for cross-communal cooperation and shaping of political affairs outside the framework of the dominant discourses advocating for Enosis or Taksim. This configured into the core ideological outlook of the two communities with the advent of independence. In other words, the division within the society was already well embedded by 1960 and was naturally extended well into the new state of affairs. Only this time, it bore a constitutional birthmark.

The communal system of political representation did not allow for bicommunal parties to engage into the political sphere, excluding in this way any real convergences. Even the example of PEO, the left-wing workers' union that had achieved in having a bi-communal membership, lost much of its Turkish Cypriot members under the pressure of nationalistic rhetoric. ${ }^{25}$ Hence, the new constitutional setting did not include anything that would allow the forging of a new Cypriot 
consciousness based on a civic patriotism. To the contrary: Cypriot citizens were confined to the boundaries of their ethnic community that inescapably shaped not only inter-communal relations at all levels, but also all future plans for a solution. This is what we consider one of the most serious failures of the Constitution of Cyprus: the fact that it failed to create a unitary Cypriot demos and shared public spheres where synergies among citizens would be fostered. ${ }^{26}$

Despite the fact that parts of the Constitution have either remained inactive or substantially amended through subsequent constitutional practice and the doctrine of necessity, bi-communality survives until today. The Constitution, read in the light of present day conditions prevailing in and outside the island, does not realistically offer a framework for a comprehensive solution to the Cyprus problem. However, its founding stone survives, and is even more enhanced, in the proposals for reaching a solution. Bi-communality has burgeoned its "bi-" nature in new areas, creating the "credo" of negotiations. For decades the two communities are ostensibly committed to reaching a solution, which would configure as a bi-communal, bi-zonal federation with political equality, as defined by $\mathrm{UN}$ resolutions. The surviving and revamped 1960 bi-communality is examined in the second part of the article.

\section{The Annan Plan}

1. From a "functional federation" to a bi-zonal and bi-communal federation

As we already mentioned, both communities were looking at the 1960 arrangement as merely a step towards the accomplishment of their aspirations. Thus, inevitably, RoC's consociational constitutional structure was questioned from the very first years of its life. In the aftermath of the 1963-4 inter-communal conflict, the two communities together with the three Guarantor States and the UN started negotiating 
again in order to find a viable solution for Cyprus. Such efforts were intensified after the 1974 Turkish invasion.

In the aftermath of the Turkish intervention and the consequent territorial segregation of the two communities, however, a settlement like the one designed by the 1960 Cyprus Agreements, was deemed inadequate. From then on, any proposal for a settlement had to include some form of Turkish Cypriot territorial entity. The Acheson Plan, the proposals by UN mediator Galo Plaza, the Gobbi Initiative, the First and Second Sets of Ideas are some of the past proposals for a settlement of the Cyprus problem that exhibit this transition to more entrenched forms of bicommunalism entailing bi-zonality as well.

In fact, all the plans drafted by the UN were largely based on the principles of bi-zonality, bi-communality and political equality of the two communities. Those three principles, being the basic parameters of the settlement of the Cyprus issue, were first introduced by the High Level Agreements of 1977 and 1979 between the then leaders of the two communities. They have been part of the narrative of the Cyprus conflict since then. Nevertheless, one has to mention the differences between how the two communities interpret those concepts and envisage the application of those principles.

For instance, the former President Christofias has stressed that the Greek Cypriot community had exhausted its limits with the major concession made by President Makarios in 1977, according to which the solution will be based on a bizonal, bi-communal federation, and thus it cannot go any further. "Neither a confederation, nor a new partnership of two states through 'virgin birth' can be accepted. The federal solution will be a partnership of two communities". 27 
In response, the former leader of the Turkish Cypriot community attached great importance to

"the continuation of the 1960 Treaties of Guarantee and Alliance as an essential part of a settlement; safeguards to ensure that neither side can claim jurisdiction over the other; and maintaining the internal balance between the two sides in Cyprus as well as the external balance between Greece and Turkey over Cyprus". ${ }^{28}$

He also reaffirmed that the community he represented has "no intention of giving up their rights over the island of Cyprus. We know that these rights of ours can be safeguarded by "the political equality of the two peoples and the equal status of the two constituent states". ${ }^{29}$

The differences in the way the two ethno-religious communities approach the basic parameters of the comprehensive settlement and which particular aspects they have decided to focus upon are obvious. Be that as it may, one has to highlight that both communities agree that the solution entails a bi-zonal, bi-communal federation with political equality, as defined by relevant Security Council resolutions, with a single sovereignty, citizenship and international personality. ${ }^{30}$ It is exactly those principles that the UN has adequately defined both in Security Council Resolutions and Reports of the Secretary-General.

First of all, the term "political equality" of the two communities has been defined in Resolution 716 (1991), which refers to the UN Secretary-General's Report of 8 July 1990. In paragraph 11 of this Report, the then UN Secretary-General Perez de Cuellar sustains that although "political equality does not mean equal numerical participation in all federal government branches it should be reflected in various 
ways". Most importantly, it entails "the effective participation of both communities in all organs and decisions of the federal government".

On the other hand, the definition of the term "bi-zonal and bi-communal federation" appears in paragraphs 17 to 25 of the Report of Boutros Boutros-Ghali of 3 April 1992. Security Council Resolution 750 (1992) has endorsed these paragraphs, and they provide as follows:

"The federal state of Cyprus will have a single international personality and sovereignty as well as a single citizenship. The two communities reject as options union in whole or in part with any other country and any form of partition or secession. The federation will be bi-communal as regards the Constitutional aspects and bi-zonal as regards the territorial aspects. The bizonality of the federation is reflected in the fact that each federated state would be administered by one community, which would be guaranteed a clear majority of the population and of land ownership in its area. The freedom of settlement and the right to property would be implemented in a manner consistent with the Constitution that would be based on the principle of bizonality."

The Security Council has never reversed these principles. Instead, they have been verified, developed and incorporated in the UN settlement proposals. ${ }^{31}$ More importantly, they have also been reaffirmed in the course both of the previous and the current round of bi-communal negotiations. ${ }^{32}$

2. The structure of the United Cyprus Republic (UCR)

So, unsurprisingly, the Annan Plan, which was presented to the two communities on 31 March 2004 in Burgenstock (Switzerland), also follows the principles of bi- 
zonality, bi-communality and political equality. The United Cyprus Republic, as envisaged in the Annan Plan, would have been a federal State modelled on the principle of consociational democracy, ${ }^{33}$ as it has successfully been adopted in the Constitutions of Switzerland and Belgium.

In the case of UCR, segmental autonomy would have been institutionalized in the form of federalism in accordance with the principle of bi-zonality. Reunified Cyprus would have been an independent and sovereign State, which would have consisted of two constituent States, namely the Greek Cypriot constituent State and the Turkish Cypriot constituent State. The status and relationship of UCR, its federal Government, and its constituent States, was modelled on the status and relationship of Switzerland, its federal Government, and its cantons. ${ }^{34}$

Bi-communality would have served as the basic standard of political representation, public service appointments, and allocation of public funds. The overrepresentation of the Turkish Cypriot segment was adopted as a safeguard of the viability of the new State since the two communities had acknowledged each other's distinct identity and integrity and that their relationship is not one of majority and minority, but of political equality. ${ }^{35}$

The political equality and the autonomy of the two ethno-religious segments inside UCR's political system were also reflected citizenship arrangements of the new State. ${ }^{36}$ Although there was a single Cypriot citizenship, every person holding it would also have enjoyed internal constituent State citizenship status. ${ }^{37}$ Despite the fact that such a status would have been complementary to, and would not have replaced, the Cypriot citizenship, it would have consisted of the deciding criterion for any provision that would refer to the constituent State origins of a person. Thus, it 
would have been a clear depiction of the autonomy of the two ethnic groups of the United Cyprus Republic.

More analytically, the federal Government would have sovereignly exercised the powers specified in the Constitution. ${ }^{38}$ The Office of the Head of State would have been vested in the Presidential Council, which would have exercised the executive power. ${ }^{39}$ The Council would have had six voting members, which would have been elected by Parliament for a fixed five-year term on a single list by special majority. Parliament could also elect additional non-voting members. The composition of the Council would have been proportional to the population of each constituent State, although at least one third of the members should have hailed from each constituent State. ${ }^{40}$ Given the numbers of the Greek Cypriot and the Turkish Cypriot population, this rule would practically mean that UCR's Presidential Council would have comprised four Greek Cypriot and two Turkish Cypriot voting members.

In addition to the rule on the composition of the Council, in which the characteristic of power-sharing was clearly reflected, the Constitution was providing for a rule according to which the Council would have strived to reach all decisions by consensus. ${ }^{41}$ Where it would have failed to reach consensus, it would have made decisions by simple majority of members present and voting. Such majority, however, should have, in all cases, comprised at least one member from each constituent State. Practically, this would have meant that the two Turkish Cypriot voting members of the Presidential Council could have been able to block a decision in order to protect the interests of the Turkish Cypriot community, in accordance with the principle of political equality. In essence, this would be the transformation of the original veto right of the Turkish Cypriot Vice-President under the London-Zurich arrangement. 
The constituent States were of equal status in order for the principle of political equality of the two ethno-religious communities to be strengthened. ${ }^{42}$ Within the limits of the Constitution and within their territorial boundaries, they would have sovereignly exercised all powers not vested in the federal Government. To this effect, the Constitutions of the two Constituent States were declaring the loyalty of those entities to UCR's Constitution. ${ }^{43}$

The federal parliament would have been composed of the Chamber of Deputies and the Senate. ${ }^{44}$ Each Chamber would have had 48 members. The Chamber of Deputies would have been composed of deputies from both constituent States. The seats would have been attributed on the basis of the number of persons holding internal constituent State citizenship status. Each constituent State would have had at least one quarter of the seats. The minorities, being the Maronites, the Latins and the Armenians, would have been represented by one deputy at least.

The Senate would have been a paritarian body composed of an equal number of Greek Cypriot and Turkish Cypriot senators. The Cypriot citizens, voting separately as Greek Cypriots and Turkish Cypriots, irrespective of their constituent State citizenship, would have elected the Senators. Clearly, such a provision would have resulted in the preservation of the ethnic cleavages in the new State. The reason being that the citizens would have voted on the basis of their ethnic affiliation and not of their constituent state citizenship. In that sense, it is par excellence an example of an arrangement that aimed at freezing a particular inter-group configuration in time by following a rather corporate consociational logic. It is a choice that would have set bi-communality in stone.

Decisions of Parliament would have needed the approval of both Chambers with a simple majority of members present and voting, including one quarter of the 
senators present and voting from each constituent State and two-fifths in the case of matters where the decision would have required a special majority. ${ }^{45}$ Hence, it would have also been possible for the Turkish Cypriot senators to veto an unfavourable decision.

Concerning the judiciary, there would have been a Supreme Court, comprised of an equal number of judges from each constituent State and three non-Cypriot judges. ${ }^{46}$ Its role would have been to uphold the Constitution and ensure its full effect. It would have had exclusive jurisdiction over disputes between the constituent States, between one or both constituent States and the federal Government and between organs of the federal Government. It would have also had exclusive jurisdiction to determine the validity of any federal or constituent State law under UCR's Constitution and primary jurisdiction over violations of federal law. ${ }^{47}$ More importantly, the Court would have been the arbiter where deadlocks would have occurred. ${ }^{48}$ In such event, the Supreme Court of Cyprus would have taken an interim decision on the matter, to remain in force until such time as the institution in question would have taken a final decision. Thus, according to the constitutional design of the Annan Plan, the body that would have been mandated to exercise judicial review in the new legal order would also have been the body that would decide on the most divisive issues.

Finally, the Annan Plan provided for the procedure for constitutional amendments. ${ }^{49}$ Apart from Articles 1 and 2 of the Constitution, which are regarded as basic and thus cannot be amended, ${ }^{50}$ any constitutional amendment would have been considered and adopted by the federal Parliament after consultation with the constituent State Governments and interested sectors of society. Following their adoption by both Chambers of Parliament, the proposed amendments would have 
been submitted to referendum for approval by a separate majority of the people in each constituent State.

\section{Citizenship and citizenship rights in the UCR}

UCR would have been a bi-communal federation, but there would have been a single Cypriot citizenship. ${ }^{51}$ Moreover, all persons holding Cypriot citizenship would have also enjoyed internal constituent state citizenship status as provided for by constitutional law. Such status, attributed on the basis of the residence at the date the settlement would have come into force, would have been complementary to, and would not have replaced, Cypriot citizenship. ${ }^{52}$ It is important to note that no one would have held the internal constituent citizenship status of both constituent States. Provisions, which stated that the constitutional Law on Internal Constituent State Citizenship Status and Constituent State Residency Rights regulated the internal constituent state citizenship status, were included in the Constitutions of both the constituent Cypriot States. The constituent State citizenship status, similar to the regime in the Åland islands ${ }^{53}$ and to the EU citizenship, was designed in such a way that it would have been connected with the exercise of political rights by the UCR citizens with the exception of the election of the Senate.

However, the internal constituent State citizenship status and the principle of bi-zonality would also have meant restrictions to the exercise of certain rights in the new State. Firstly, there would have been limitation on the right of natural persons, not permanently residing in the Turkish Cypriot constituent State for at least three years, and of legal persons to purchase immovable property in that State, without permission of the competent authority of that constituent State. Those restrictions on the acquisition of property in the Turkish Cypriot constituent State should have lasted 
for 15 years or, alternatively, until the gross domestic product per capita in that constituent State remained below 85 per cent of the gross domestic product per capita in the Greek Cypriot State. The proposed authorization procedure was deemed necessary not only because of the economic disparities between the Turkish Cypriot constituent State and EU Member States, but also between the two communities. The purpose of that arrangement was to avoid unacceptable sudden price increases and a large-scale buy-out of land. ${ }^{54}$ In other words, it would have served as a safeguard clause, according to which the authorities of the Turkish Cypriot constituent State could deny the right of non-resident natural persons and legal persons to acquire property for a specific period of time. ${ }^{55}$

Moreover, apart from restrictions on the right to acquire property in northern Cyprus, restrictions on residence rights were also provided. The recognition of the particular national identity of Cyprus and the need for protection of the balance between Greek Cypriots and Turkish Cypriots in Cyprus, the bi-zonal character of the UCR and the distinct identity and integrity of the constituent States necessitated certain safeguards and temporary restrictions on the residence rights of Cypriot citizens, as well as citizens of Greece and Turkey. ${ }^{56}$ Article 2 of the Draft Act of Adaptation (DAA) provided for the terms that would have applied to the right to residence of the Cypriot citizens in the constituent States of the UCR. According to it, restrictions on the right of Cypriot citizens to reside in a constituent State of which they would not have held the internal constituent State citizenship status, should not have been precluded in the form of a moratorium during the first five years of the life of the reunified State, notwithstanding existing provisions of EU law. Later on, between the sixth and ninth years, the percentage of people not holding the relevant constituent State citizenship status could not exceed six per cent of the total 
population of the respective municipality or village. This percentage would have been doubled between the tenth and fourteenth years. For the following five years, or until Turkey's accession, the relevant percentage could have reached 18 per cent. Finally, after the nineteenth year, following the establishment of a new state of affairs, either constituent State could, with a view to protecting its identity, take safeguard measures to ensure that no less than two-thirds of its permanent residents speak its official language as their mother tongue.

Clearly, all those restrictions are in stark contrast with the international conventions that have been put in place in support of the rights of individuals from a liberal perspective such as the European Convention of Human Rights and the EU Charter of Fundamental Rights. Although the restrictions on the right to residency and property of the Cypriot citizens within their own State could be potentially justified because they would serve the public policy goal of the reunification, they have been underlined as important reasons for the rejection of the Annan Plan by the Greek Cypriot community. ${ }^{57}$ But could they have realistically been avoided?

\section{Understanding an inherent contradiction}

A famous quote by Massimo d' Azeglio says: "L'Italia è fatta. Restano da fare gli italiani" [Italy has been created. It remains for Italians to be created.] and it seems to us that in certain perspectives the same holds true for the case of Cyprus. What we have attempted to explore so far in this article is how bi-communality is deeply rooted in the constitutional structure of the Republic and in the Annan Plan as the most comprehensive and detailed attempt to resolve the Cyprus problem. Although space constraints did not allow for an in-depth comparative study of all proposals for its 
resolution, we can nonetheless confirm that bi-communality is a permanent building block.

One might argue that this happens at the expense of a nation-building procedure that could allow for the bridging of the cleavages between the two ethnoreligious segments. However, both the political environment on the island and certain normative concerns on the state-building of divided societies might suggest that bicommunality is a necessary condition for the establishment of a reunified State. In other words, Cyprus demonstrates a certain contradiction. On the one hand, external actors and local moderates wish to see the island and its people reunited on the other the specific institutional solutions suggested are divisive as shown in a number of provisions of the Annan Plan. ${ }^{58}$

However, Cyprus is by no means unique. Such contradiction exists in conflict resolution practice in a number of divided societies where segmental autonomy and strict ethnic representation are used in order to keep all ethno-religious groups appeased. To a certain degree, this is unavoidable not least because the institutional designing of a post-conflict society is often characterized by 'a joining together of constituent units which do not lose their identity when merging in some form of union' ${ }^{59}$ In any case, the consociational model of democracy ${ }^{60}$ which most of those institutional structures (including the ones in Cyprus) adopt entails that every significant segment of the society proportionately participates in the government of the country while it retains a high degree of autonomy and the possibility to veto decisions of the majority in order to protect its vital interests. So, it is almost inevitable that constitutional systems that secure such a high degree of segmental autonomy will not be centered on the idea of "one nation, one state".

Post-Dayton Bosnia is probably the most striking example of such an 
institutional designing in Europe. This (con)federal State is comprised of two ethnically defined entities: a Serb one and a Bosniak-Croat one, ${ }^{61}$ which enjoy wideranging powers of self-government. ${ }^{62}$ More importantly, strict ethnic representation of the three constituent peoples is required for the Presidency, ${ }^{63}$ the upper chamber of the legislature, ${ }^{64}$ the Constitutional Court ${ }^{65}$ and the Central Bank. ${ }^{66}$ What is interesting to note in this case is that although the role of the international community in the constitutional steering of Bosnia cannot be overestimated, it is an international actor that has cast doubt with regard to the logic of the strict ethnic representation embodied in the system. The European Court of Human Rights in the famous Sejdic and Finci ${ }^{67}$ held that the "inexistence of the right for the non-constituent peoples to stand for election to the collective State Presidency and to the House of Peoples ${ }^{68}$ breaches the European Convention.

Notwithstanding the decision of the Strasbourg Court, it is interesting to note how embedded are in the constitutions of Bosnia and in the Annan Plan both the segmental autonomy of the main ethno-religious groups and the link between ethnic identity and the exercise of political rights. Similar provisions securing the legislative autonomy of the main segments of a society can be found in a number of post-conflict arrangements. For instance, the Ahtisaari Plan was envisaging 'an enhanced and sustainable system of local self government in Kosovo' giving to the Serbian municipalities full and exclusive powers on a number of areas. ${ }^{69}$ Such solution was also adopted in the EU-brokered 15-points Agreement between Serbia and Kosovo in $2013 .^{70}$ Similarly in Macedonia, according to section 3(1) of the Ohrid Agreement the signatory parties undertook the responsibility to adopt a revised law on local selfgovernment entailing enhanced competences in a number of areas. But it is not only post-conflict arrangements that opt for segmental autonomy. Some constitutional 
systems of consolidated democracies that aim at accommodating ethno-linguistic conflicts use it as well. One does not have to look further than the constitutions of Spain and Belgium in order to find ethnic and linguistic communities that enjoy a high level of legislative autonomy. ${ }^{71}$

Apart from Bosnia and Cyprus, provisions of strict ethnic representation can be also found in Kosovo. Article 64(2) of the Constitution provides that minimum ten seats are reserved to the Kosovo Serb Community and another ten for the other minorities. But perhaps the most interesting example is the Good Friday Agreement, which created a power-sharing arrangement between the two main ethno-religious segments. Following the 2006 Saint Andrews Agreement, the First Minister is nominated by the largest political party in the Northern Ireland Assembly while the Deputy First Minister by the largest political party of the other political designation. ${ }^{72}$ So, if the First Minister comes from the 'Unionist' political designation, the Deputy First Minister will come from the 'Nationalist' one and vice versa. More interestingly, the ministers are not chosen by this diarchy. Instead, the Northern Ireland Act 1998 provides that the ministerial posts are allocated to all of those parties with significant representation in the Assembly. The number of posts to which each party is entitled, is determined according to the d'Hondt method of proportional representation. The actual posts are chosen by the parties in the order that the seats were awarded. This does not mean that apart from the two largest parties, the other parties are required to enter the Executive. They can choose to go into opposition if they wish. ${ }^{73}$

So, the institutional arrangements suggested for Cyprus according to which segmental autonomy and strict ethnic representations are used in expense of a nationbuilding process are far from an exception. In fact, the same contradiction can be found in a number of European constitutions that aim at accommodating an ethno- 
linguistic conflict. Bosnia, Kosovo, Macedonia and Northern Ireland, among else, provide for such examples.

\section{E. In lieu of a conclusion}

What we have argued so far is that bi-communality has a Janus-like face: one side of it features as an indispensable element to any future solution, but the other seems to perpetuate the seed of division along the lines of communal affiliation. ${ }^{74}$ This is something that one can observe in almost every arrangement that has consociational characteristics. Yet, the perennial question remains what a commentator phrased as the innovation of "a method whereby, over time, Cypriot nationality would trump communal affiliation". 75

Concerning the political environment one has to note that according to the “Cyprus 2015" opinion polls, ${ }^{76}$ Greek Cypriots would ideally prefer a unitary state but would be prepared to live with a bi-zonal bi-communal federation. At the same time, Turkish Cypriots would ideally prefer a two-states solution, but would accept a bi-zonal bi-communal federation. This might suggest that bi-communality offers the necessary middle ground for the achievement of the long-awaited comprehensive settlement.

In any case, it seems that in order for a plan for the comprehensive settlement of the Cyprus issue to be successful, it should be characterized by what Christine Bell, citing Ramsbotham, calls "Clausewitz in reverse". ${ }^{77}$ Claus von Clausewitz described war as "simply a continuation of political intercourse, with the addition of other means". ${ }^{78}$ According to the "Clausewitz in reverse" view, then, a future peace agreement on the Cyprus issue should be viewed in converse terms, as a legal document which embraces politics as the continuation of the conflict of the two 
communities by other means. The preservation and incorporation of all the clashing claims at the heart of the conflict would paradoxically aim to transform it away from the current stalemate, by designing political and legal institutions in which the conflict can continue to be negotiated. In other words, the future settlement plan should be recognized as a forum of meta-constitutional debate, a debate as to what type of constitutional vision will prevail at the domestic level. ${ }^{79}$ Such an approach would also favour bi-communality as a distinct element of the future Cypriot Constitution.

In this connection, the proposal for a rotating presidency with cross-voting actually moves towards the direction we endorse. ${ }^{80}$ In effect, both elements of this proposal reconcile facially conflicting parameters: on the one hand, the rotation of the office of the President embodies bi-communality and political equality of the two communities, while, on the other hand, establishing a common political forum for the two electoral constituencies by providing the opportunity to influence the outcome of the elections in the other community. The added value of this proposal is that it breaks away from the traditional negotiating paradigm and espouses a different model of statecraft.

And a final point: beyond devising meticulous details of a bi-communal constitutional design, lies the fundamental question of its actual functionality. Notwithstanding the final outcome of the negotiation process, a functional solution will not so much rely on these details, but rather on the goodwill and genuine commitment of the two communities and their political elites; precisely the elements that were missing during the initial years of the Republic.

\section{ACKNOWLEDGEMENTS}


We would like to thank Adrian Guelke, Neophytos Loizides, Iosif Kovras and the journal's anonymous reviewers whose comments helped us improve this article from its original version. The usual disclaimer applies.

\section{NOTES}

\footnotetext{
${ }^{1}$ For a summary of the Cyprus negotiations since 1963 see eg Ahmet Sözen, "The Cyprus negotiations: From the 1963 Inter-communal negotiations to the Annan Plan” in Ahmet Sözen, ed., Reflections on the Cyprus Problem: A Compilation of Recent Academic Contributions (Famagusta: Cyprus Policy Centre, 2007), 1.

${ }^{2}$ Allison McCulloch, "Consociational settlements in deeply divided societies: the liberal-corporate distinction" Democratization 21(3): 501-518 (2014). We are grateful to Adrian Guelke for this point.

${ }^{3}$ Art II of the Treaty of Guarantee.

${ }^{4}$ Art III of the Treaty of Guarantee.

${ }^{5}$ Art IV of the Treaty of Guarantee.

6 Paschalis Kitromilides, "The dialectic of intolerance: ideological dimensions of ethnic conflict," Journal of the Hellenic Diaspora VI (4): 5 (1979).

${ }^{7}$ Art 1 of the Constitution.

${ }^{8}$ Art 182(1) of the Constitution.
}

${ }^{9}$ Michalis Attalides, "Relations Between Greek Cypriots and Turkish Cypriots," in George Tenekides and Yiannos Kranidiotis, eds., Cyprus: History, Problems and Struggles of its People (Athens: Estia, 1981), 426.

${ }^{10}$ James Ker-Lindsay, The Cyprus Problem - What everyone needs to know (Oxford: Oxford University Press, 2011) 21 and 34; Clement Dood, The history and politics of the Cyprus conflict (Basingstone: Palgrave Macmillan, 2010), 41.

${ }^{11}$ The then Minister Yorkadzis stated that: "The Struggle of EOKA will continue with other means to meet its fruition according to the expectations of the Pan-Hellenes" [authors' translation] quoted in

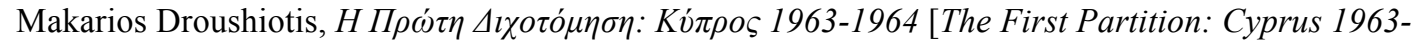
1964] (Nicosia: Alfadi, 2005), 31.

12 Ibid, 29.

${ }^{13}$ Stella Soulioti, Fettered independence: Cyprus, 1878-1964 (Minneapolis: Minnesota Mediterranean and East European Monographs, 2006), 627-638.

${ }^{14}$ Full text quoted in Politis newspaper, 15 August 2010, p. 5.

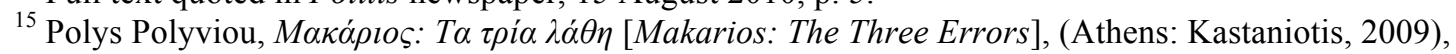
21.

${ }^{16}$ Aziz v. Cyprus, (Application no. 69949/01) European Court of Human Rights, 22 June 2004, para. 29

${ }^{17}$ Ali Erel and Mustafa Damdelen v. Cyprus, (Application no. 39973/07) European Court of Human Rights, 14 December 2010.

${ }^{18}$ By way of example, see: http://www.berghofconflictresearch.org/documents/publications/boc21gt.pdf (accessed 4 July 2016) and AKEL's political position: http://www.akel.org.cy/?p=839 (accessed 4 July 2016).

${ }^{19}$ See Art 6 of the Treaty of Establishment and Art 198 of the Constitution.

${ }^{20}$ Ibid.

${ }^{21}$ Nikos Trimikliniotis and Nikoletta Charalambidou, Cyprus Country Report, http://eudocitizenship.eu/country-profiles/?country=Cyprus (accessed 4 July 2016).

${ }^{22}$ Ioannis Stefanidis, Isle of Discord-nationalism, imperialism and the making of the Cyprus problem (London: Hurst and Company, 1999), 207-254.

${ }^{23}$ Julie Ringelheim, "Minority protection and Constitutional recognition of difference," in Annelies Verstichel, Bruno De Witte, Paul Lemmens, and André Alen, eds., The Framework Convention for the Protection of National Minorities: A Useful Pan-European Instrument? (Mortsel: Intersentia, 2008), 43.

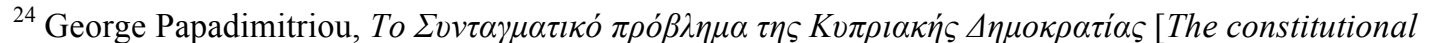
problem of the Republic of Cyprus], (Athens: Sakkoulas, 1997), 30-31. 
${ }^{25}$ Although, AKEL (Progressive Party of the Working People) had Turkish Cypriot members at the time, this cannot be taken to suggest a filling of the political cleavage.

${ }^{26}$ Kizılyürek argues that Cypriot unity should be founded on a meta-ethnic constitutional patriotism, based on common principles of justice and democracy: Niyazi Kız1lyürek, Cyprus: impasse of nationalisms (Athens: Mavri Lista, 1999), 146.

${ }^{27}$ Dimitris Christofias, Opening Statement for the bi-communal negotiations [on file with the authors] (2008)

${ }^{28}$ Mehmet Ali Talat, Opening Statement for the bi-communal negotiations [on file with the authors] (2008).

${ }^{29}$ Ibid.

${ }^{30}$ See for example the $8^{\text {th }}$ July Agreement between the then President of the Republic, Mr Tassos Papadopoulos, and the then Turkish Cypriot leader, Mr Mehmet Ali Talat. In this, they decided to confirm their "commitment to the unification of Cyprus based on a bi-zonal, bi-communal federation and political equality, as set out in the relevant Security Council Resolutions". This agreement was reconfirmed on 21 March 2008 by the following President of the Republic, Mr Christofias, and Mr Talat and in late May 2010 - after the election of Mr Eroğlu as the President of the internationally unrecognised TRNC.

${ }^{31}$ See in particular in particular UN Security Council Resolution 1251 (1999).

${ }^{32}$ UN Security Council Resolution 1898 (2009), para. 5; Joint Declaration of the leaders of the two communities, issued on 11 February 2014, available at: http://www.uncyprustalks.org/media/Good\%20Offices/Photos\%20For\%20Main\%20Articles/FEBRUA RY_2014_JOINT_DECLARATION_FINAL.pdf (accessed 4 July 2016).

${ }_{33}$ Arend Lijphart, Democracy in Plural Societies (London: Yale University Press, 1977); Arend Lijphart, Patterns of Democracy: Government Forms and Performance in Thirty-Six Countries (London: Yale University Press, 1999).

${ }^{34}$ Arts 2(1) of the Foundation Agreement and 1(1) of the UCR Constitution.

${ }^{35}$ Main Art iii of the Foundation Agreement,

${ }^{36}$ Art 3 of the Foundation Agreement and Art 12 of the UCR Constitution.

${ }^{37}$ See Annan Plan's Constitutional Law on Internal Constituent State Citizenship Status and Constituent State Residency Rights.

${ }^{38}$ Art 2(1)(b) of the Foundation Agreement.

${ }^{39}$ Art 26 of the UCR Constitution.

${ }^{40}$ Art 26(6) of the UCR Constitution.

${ }^{41}$ Art 26(7) of the UCR Constitution.

${ }^{42}$ Art 2(1)(c) of the Foundation Agreement and Arts 2 and 15 of the UCR Constitution.

43 Art 3 of the Constitution of the Greek Cypriot constituent State and Art 4 of the Constitution of the Turkish Cypriot constituent State.

${ }^{44}$ Art 5(1) of the Foundation Agreement and Art 22 of the UCR Constitution.

${ }^{45}$ Arts 5(1) of the Foundation Agreement and Art 22 of the UCR Constitution. Art 25(2) of the Constitution provides for an exclusive list of matters, which specifically require special majority approval.

${ }^{46}$ Art 6 of the Foundation Agreement and Art 36 of the UCR Constitution.

${ }^{47}$ Art 36 of the UCR Constitution.

${ }^{48}$ Art 36(5) of the UCR Constitution.

${ }^{49}$ Art 2(4) of the Foundation Agreement and Article 37 of the UCR Constitution.

${ }^{50}$ Art 37(2) of the UCR Constitution.

${ }^{51}$ Art 3 of the Foundation Agreement and Art 12 of the UCR Constitution.

${ }^{52}$ Arts 3(2) of the Foundation Agreement and 12(2) of the UCR Constitution.

${ }^{53}$ See generally The Åland Agreement in the Council of the League of Nations, 1921, League of Nations Official Journal, 701, September 1921.

${ }^{54}$ Recital xii of the Draft Act of Adaptation (hereafter DAA), Appendix D of the Annan Plan.

${ }^{55}$ Art 1(2) DAA.

${ }^{56}$ Recital vii DAA.

${ }^{57}$ See the speech of the late Greek Cypriot President Tassos Papadopoulos, Press Release, Press and Information Office, Republic of Cyprus, 7 April 2004.

${ }^{58} \mathrm{We}$ are grateful to the anonymous reviewer for this comment.

${ }^{59}$ David Apter, The Political Kingdom in Uganda: A Study in Bureaucratic Nationalism. (Princeton, NJ: Princeton University Press, 1996) 24. 
${ }^{60}$ See among else, Lijphart, Democracy in Plural Societies; Sue Halpern "The Disorderly Universe of Consociational Democracy", West European Politics 9: 181 (1986); Kenneth Douglas McRae, ed., Consociational Democracy (Toronto: McClelland and Stewart Limited, 1974).

${ }^{61}$ For a comprehensive analysis of the BiH Constitution see Florian Bieber, "Power-sharing and International Intervention: Overcoming the Post-Conflict Legacy in Bosnia and Herzegovina" in Marc Weller and Barbara Metzger, eds., Settling self-determination disputes: complex power-sharing in theory and practice (Leiden / Boston: Martinus Nijhoff Publishers, 2008) 193.

${ }^{62}$ Arts III(1) and III(3)(a) of the BiH Constitution.

${ }^{63}$ Art V of the BiH Constitution.

${ }^{64}$ Art IV(1) of the BiH Constitution.

${ }^{65}$ Art VI of the BiH Constitution.

${ }^{66}$ Art VII of the BiH Constitution.

${ }^{67}$ Sejdić and Finci vs. Bosnia and Herzegovina, (Application nos. 27996/06 and 34836/06) European Court of Human Rights, 22 December 2009.

${ }^{68}$ Jelena Džankić "The Politics of Inclusion and Exclusion: Citizenship and Voting Rights in Bosnia and Herzegovina" International Peacekeeping 22: 526, 527.

${ }^{69}$ Preamble of Annex 3 on Decentralisation of the Ahtisaari Plan.

${ }^{70}$ Full text available at:

http://www.b92.net/eng/news/politics.php?yyyy=2013\&mm=04\&dd=19\&nav_id=85799 (accessed 4 July 2016).

${ }^{71}$ Nikos Skoutaris, Territorial Pluralism in Europe, Vertical Separation of Powers in the EU and its Member States (Oxford: Bloomsbury, 2017).

${ }^{72}$ Read conjunctively sections 16A, 16B and 16C of the Northern Ireland Act 1998.

${ }^{73}$ See Assembly and Executive Reform (Assembly Opposition) Act (Northern Ireland) 2016.

${ }^{74}$ Neophytos Loizides, "Ethnic nationalism and adaptation in Cyprus," International Studies Perspectives 8: 172-189 (2007).

${ }^{75}$ Robert Rotberg, "Reunifying Cyprus: Essential Challenges," in Andrekos Varnava and Hubert Faustmann, eds., Reunifying Cyprus - The Annan Plan and beyond (London: I.B. Tauris, 2011), 253.

${ }^{76}$ Available at http://www.seedsofpeace.eu/ (accessed 4 July 2016). For an analysis of the special category of "settlers" see Mine Yücel, "The First Official UN Opinion Poll in Cyprus: An In-Depth Analysis of the Media and the Turkish Immigrants/Settlers" in Ahmet Sözen, ed., The Cyprus Conflict: Looking Ahead (Famagusta: Cyprus Policy Centre, 2008), 277.

${ }^{77}$ Christine Bell, On the Law of Peace, (Oxford: Oxford University Press, 2008), 200.

${ }^{78}$ Karl von Clausewitz, On War (Princeton: Princeton University Press, 1976).

${ }^{79}$ Bell, On the Law of Peace, 293.

${ }^{80}$ This approach actually responds to the point made by Schneckener, that "generally presidential systems seem to be less suitable for consociationalism than cabinet systems". See Ulrich Schneckener "Making Power-sharing Work: Lessons from Success and Failures in Ethnic Conflict Regulations", Journal of Peace Research 39(2): 203, 220 (2002).

Nikolas Kyriakou is an advisor at the International Law Section of the Law Office of the Republic of Cyprus and an adjunct lecturer at the University of Cyprus. His doctoral thesis at the European University Institute (Florence) was on the practice of enforced disappearances viewed from an international human rights law perspective. He has published on issues pertaining to human rights, enforced disappearances, EU law and the protection of minority rights.

Nikos Skoutaris is a Lecturer of EU Law in the UEA Law School. His research lies in the intersection between EU law, comparative constitutional law and conflict resolution. His doctoral thesis was published as a monograph with a leading publisher (The Cyprus Issue: the four freedoms in a (member-) state of siege) (Hart Publishing 2011). At the moment he is finalizing his second monograph. (Territorial Pluralism in Europe: Territorial Pluralism in Europe: Vertical separation of powers in the EU and its Member States (Oxford, Hart Publishing, forthcoming in 2016)). His current 
research focuses on the constitutional accommodation of ethno-territorial conflicts in Europe. 